\title{
CURRENT RESEARCH ON PHYTOPATHOGENIC FUNGI: AN OVERVIEW
}

\author{
F. VIRÁNYI
}

Gödöllô University of Agricultural Sciences, Gödöllô, Hungary

The majority of plant pathogens comprising about $60 \%$ of the total are belonging to a group of eukaryotic microorganisms, commonly known as FUNGI although this name obviously covers a number of organisms that are not fungi in a strict sense [1]. Yet, all these plant pathogens, having different systematic positions within the livings, are of significance as far as agricultural crop production is concerned.

Mycologists in the past were primarily interested in identifying fungal diseases, describing the fungi, studying their life cycle in relation to environment and looking for effective control measures. A big step forward was when investigations expanded toward the physiology of plant diseases and disease resistance. Meanwhile fungal genetics has developed providing a better understanding of plant-fungus relations. Recently, with the introduction of molecular techniques, new approaches of research, such as molecular taxonomy and molecular genetics have been established and the molecular methods were applied in other related fields of studies.

For the illustration of changes in research interest worldwide, the main research topics and all the contributions (poster presentations) accepted at and published by the 7th International Congress of Plant Pathology held in Edinburgh, Scotland between 9-16 August 1998 have been scanned. Based on these, some of the most promising research trends with a few examples will be accounted here and then a short overview of what has recently been done by Hungarian mycologists on the subject will be given.

\section{Research tendencies in the World}

Detection and identification. No doubt, modern diagnostic technology started in 1976 with the first application of ELISA to plant virus detection. Subsequently, assays have been targeted to the detection of plant pathogenic fungi. ELISA kits are now commercially available and ELISA and other related antibody-based technologies are widely used. As an example, Jennings et al. [2] have raised Mabs (monoclonal antibodies) to either the Fusarium genus or individual species, such as F. avenaceum, F. culmorum and $F$. poae. Further, the use of protein and enzyme profiles have also been established as 
tools of differentiating between fungal species/strains. Belisario et al. [3] found Monilinia fructigena, M. fructicola and M. laxa, the brown rot pathogen of fruits distinguishable based on protein patterns.

The practical use of nucleic acid-based detection technologies in plant pathology was limited until the introduction of the polymerase chain reaction (PCR) assay in the late 1980s. Afterwards, however, PCR or reverse transcription (RT) PCR have been developed for a wide range of plant pathogens including phytopathogenic fungi, and the combination of PCR and DNA hybridization allowed the detection of multiple pathogens in a single test. The only limiting factor of widespread application of these techniques is their expensiveness. One of the most promising uses of DNA technologies in the plant pathological practise is the detection of latent (symptomless) infection by fungal pathogens in plants. For example, Whisson et al. [4] were able to produce taxon-specific DNA probes derived from DNA extracted from both Phomopsis viticola conidia and infected grapevine tissues. A PCR-based assay then allowed the detection of the fungus from symptomless plants.

Apart from molecular methods, there are improved microscopical techniques, like image analyses or comparative electron microscopy (SEM and TEM) of spores, suitable for discriminating between uncertain species [5, 6].

Genetic and molecular aspects of pathogenicity. Within the last few years, the application of molecular genetic methods has enabled the identification of a variety of genes involved in pathogenesis, such as determinants of early infection stages, colonization and of fungal products killing plant cells. One of the most exciting questions is what are the signals influencing spore germination and host penetration, in other words, what are the factors responsible for mutual recognition and subsequent events leading to disease. With the rice blast fungus, Magnaporthe grisea, for example, thigmotrophic sensing appeared to involve a fungal cell-surface protein called Mpg-1 that belongs to the known hydrophobins [7]. Another point of interest relates to the presence of specific proteins of fungal origin, called elecitins, the recognition of which by the host plant is a prerequisite of events leading to either compatibility or incompatibility. By means of molecular methods it was possible to clone elicitin genes from the fungus Phytophthora sojae [8].

Necrotrophic fungi require a rapid death of plant cells to get into contact with host nutrients. Therefore, a wide range of secondary metabolites, like phytotoxins and lytic enzymes produced by them prior to, during and after penetration are considered to play a role in pathogenesis. In fact, by isolating and cloning the genes governing the production of pectinases and lipases, Ten Have et al. [9] elucidated their significance.

Since P J G M de Wit and his co-workers [10] were successful in cloning first an avirulence gene from the fungus Cladosporium fulvum, additional avirulence genes have been identified in different laboratories, e.g. in Australia [11] and in the UK [12].

Genetic diversity of fungal populations. The mechanisms of population genetics over space and time appear to be rather complex and multifactorial. However, there are increasing experimental evidences that genetic structures of phytopathogenic fungi are basically influenced (determined) by mating systems, immigration (gene flow) and selection [13] as well as by somatic heterokaryosis [14]. 
From the practical point of view, population changes as variation in virulence, aggressiveness or fungicide-sensitivity are being of particular interest. Accordingly, the number of investigations using either conventional methods (host differentials, mating analysis), molecular techniques (DNA polymorphism) or both have markedly been increased. Recently, Pipe et al. [15] applied, as a new tool, microsatellite markers with Phytophthora infestans for the analysis of diversity in population structure.

Response to environment. Ecology of phytopathogenic fungi came to the focus recently in many mycological laboratories. Of particular interest are investigations looking at the survival and growth of fungi in soils of various qualities, as well as the various biotic interactions including those between pathogenic and non-pathogenic species [16]. To study the complexity of such soil systems and to elucidate the processes taking place in the rhisosphere, molecular approaches, e.g. the use of GUS-transformants of Trichoderma harzianum have been applied [17]. Since many of the non-plant pathogenic soil microorganisms are considered as potential biocontrol agents, techniques of isolation and characterization and mass-production of the candidates have been the subject of studies worldwide. In addition, as a most promising tool, the so-called molecular breeding of some of the biological antagonists were initiated [18].

\section{Research progress in Hungary}

Much of our studies on phytopathogenic fungi, being either basic or applied, have been carried out in research institutes (MTA-NKI, MBK, MTA-MgKI) and agricultural universities (GATE, PATE, DATE, KÉE, SE), respectively. Based on recent publications, a selection of research topics will be shown here to provide with a short and informative overview.

Etiology. Of particular interest are studies related to woody plant diseases (fruit and forest trees, grapevine) where newly appearing pathogens or pathogen complexes are causing severe damage $[19,20]$, or investigations of the pathogenic mycofloras of natural vs. agricultural ecosystems [21].

Detection/identification. Besides classical methods, molecular techniques in the detection and identification of phytopathogenic fungi have been introduced. For example, the comparison of pectic enzyme zymograms of Cytospora species [22], and the esterase isozyme patterns of different Fusarium species [23] permitted to distinguish between different taxons, or DNA polymorphism and RAPD analysis verified the taxonomic position of genera and species of the so-called "Helminthosporium" form complex [24].

Population structure and genetics. Much of recent studies have been focussing on inter- and intraspecific variations of some important phytopathogenic fungi and both classical methods and new molecular techniques have been applied. For example, the relative dominance of Fusarium species in winter wheat and maize [25, 26], changes in mating type, virulence pattern and fungicide sensitivity of Phytophthora infestans [27], evolutionary processes in the virulence character of field populations of Blumeria graminis, Puccinia graminis and Plasmopara halstedii [28-30] have been the subject of investigations in order to combat with these pathogens. Furthermore, PCR-RAPD 
techniques allowed to distinguish between Fusarium species belonging to the teleomorph Gibberella fujikuroi [31], and cloning a repetitive element from Fusarium poae made it possible to understand, at least in part, the genetic background of fungus variability [32].

Biological antagonists. The potential of using antagonistic fungi as biocontrol agents in agriculture has prompted Hungarian mycologists to set up and expand research in different laboratories. A wide range of investigations, from the isolation, identification and systematics of such fungi through molecular genetics to the patented bioproduct have been made e.g. with Trichoderma spp. [33], Coniothyrium minitans and Ampelomyces spp [34]. In addition, VCG groups within the Hungarian populations of Cryphonectria parasitica have been determined enhancing to characterize population structures and to detect hypovirulence, a phenomenon known to play an important role in the biocontrol process against this pathogen [35]. And another, special aspect of studies on antagonistic fungi resulted in identifying species as potential mycoherbicides [36].

\section{REFERENCES}

1. Hawksworth,D.L., Kirk,P.M., Sutton,B.C., Pegler,D.N.: Ainsworth and Bisby's Dictionary of the Fungi. CAB International, Wallingford. 1995. p. 616.

2. Jennings,P., Turner,J.A., Banks,J.N.: The effect of method of antigen preparation on the detection of Fusarium species by monoclonal antibodies. Proceedings, 7th International Congress of Plant pathology, Edinburgh, 9-16 August, 1998. Vol. 3, Abstr no. 3.3.9.

3. Belisario,A., Corazza,L., Luongo,L.: Use of total protein profiles to distinguish Monilinia species. Ibid Vol. 3, no. 3.3.71.

4. Whisson,D.L., Brant,B., Stummer,B.E., Scheper,R.W.A.: Detection of Phomopsis viticola in grapevine canes using molecular and classical techniques. Ibid Vol. 3, no. 3.3.14.

5. Lane,C.R., Jeuland,H., Hall,A.G., Chesmore,E.D.: Image analysis as an aid to discrimination between Colletotrichum acutatum and C. gloeosporioides. Ibid Vol. 3, no. 4.3.2.

6. Van Wyk,P.W.J., Kapooria,R.G.: A comparison of uredospore ultrastructure and development in Melampsora isolates occurring in Zambia. Ibid Vol. 2, no. 1.10.1.

7. Hamer,J., Adachi,K., Bhargava,T., Jin-Rong Xu, Urban,M.: Signal transduction and morphogenesis during Magnaporthe grisea infection. Ibid Vol. 1, no. 1.10.3S

8. Becker,J., Nagel,S., Tenhaken,R.: Cloning of elicitin genes from the soybean pathogen Phytophthora sojae. Ibid Vol. 2, no. 1.8.11.

9. Ten Have,A., Oude Breuil,W., Wubben,J.P., Mulder,W., Visser,J., Jal Van Kan.: Involvement of pectinases from Botrytis cinerea in plant pathogenesis: characterization, gene expression and elimination of the encoding genes. Ibid Vol 2, no. 1.8.5

10. Van Kan,J.A.L., Van der Ackerveken,G.F.J.M., De Wit,P.J.G.M.: Cloning and characterization of cDNA of avirulence gene avr9 of the fungal pathogen Cladosporium fulvum, causal agent of tomato leaf mold. Mol Plant-Microbe Interact 4, 52 (1991).

11. Whisson,S.C., Drenth,A., Maclean,D.J., Irwin Jag.: Cloning of avirulence genes from Phytophthora sojae. Proceedings, 7th International Congress of Plant Pathology, Edinburgh, 9-16 August, 1998. Vol. 2, Abstr. no. 1.1.5.

12. Brown,J.K.M., Foster,E.M., Ridout,C.J., Jones,J.D.G., Thomas,C.M.: High resolution molecular genetic mapping of Erysiphe graminis f. sp. hordei, the barley powdery mildew pathogen. Ibid Vol. 2, no. 1.8.49. 
13. McDonald,B.A., Mundt,C.C., Zhan,J.: Experimental approaches to understanding the contributions of mating system, gene flow and selection to the genetic structure of populations of plant pathogenic fungi. Ibid Vol 1, 2.2.1S

14. Cortes,B.R., Blanca,R., Kuhn,D.N., Rejane,R.: Comparison of heterokaryon formation by hyphal anastomosis and protoplast fusion in Fusarium. Ibid Vol. 2, no. 1.8.15.

15. Pipe,N.D., Gliddon,C.J., Shattock,R.C., Shaw,D.S.: Microsatellite markers for Phytophthora infestans: new tool for an old problem. Ibid Vol. 2, 2.2.38.

16. Alabouvette,C.: Biotic interactions in the soil: an overview. Ibid Vol. 1, 2.7.1S

17. Jensen,D.F., Green,H.: A molecular approach for studying autecology of fungal BCAs. Ibid Vol. 1, 3.5.6S

18. Brasier,C.M., Milgroom,M.G.: New genetics and new biocontrols for Dutch elm disease and chestnut blight. Ibid Vol. 1, 4.4.6S

19. Vajna,L.: Deterioration in the health status of European and Hungarian forests in the period 1970-1980. (in Hungarian) Növényvédelem 30, 401-409 (1994).

20. Szabó,I: Some foliage necrosis causing Coelomycetes on broad leaved forest trees and shrubs in the surrounding of Sopron, Hungary. Acta Phytopathol Entomol Hung 31, 69-78 (1994).

21. Bán,R., Fischl,G., Virányi,F.: A spatio-temporal analysis of fungal pathogens on reed in natural habitats. Acta Phytopathol Entomol Hung 31, 219-227 (1996).

22. Szécsi,Á., Rozsnyay,Zs.: Comparison of pectic enzyme zymograms of Cytopsora cincta and C. leucostoma. (in Hungarian) Növényvédelem 30, 419-422 (1994).

23. Bakonyi,J., Pomázi,A., Fischl,G., Hornok,L.: Molecular taxonomy of graminicolous species of the form complex "Helminthosporium". (in Hungarian) Növényvédelem 30, 207-214 (1994).

24. Vágújfalvy,A., Szécsi,Á.: Identification of Fusarium moniliforme, F. proliferatum and F. subglutinans based on their esterase isozyme analysis. (in Hungarian) Növényvédelem 31, 479-484 (1995).

25. Tóth,A., Szakál,M., Petróczi,I.: Dominance conditions of Fusarium species occurring in winter wheat kernels in Pest county. (in Hungarian) Növényvédelem 30, 455-460 (1994).

26. Szécsi,Á.: Occurrence of Fusarium species in section Liseola isolated from Hungarian corn samples in 1991 and 1992. (in Hungarian) Növényvédelem 30, 313-318 (1994).

27. Bakonyi,J., Érsek,T.: A threat of potato late blight in Hungary. (in Hungarian) Növényvédelem 33, 221-228 (1997).

28. Szunics,L., Szunics,L.: Evolution of wheat powdery mildew populations during 1971-1977 in Hungary. Proceedings, 7th International Congress of Plant Pathology, Edinburgh, 9-17 August, 1998. Vol. 2, Abstr. no. 2.2.114.

29. Manninger,K.: Wheat leaf rust in Hungary: virulence surveys during 1993-1997. Ibid Vol. 2, no. 2.2.101.

30. Virányi,F., Gulya,T.J.: Inter-isolate variation for virulence in Plasmopara halstedii (sunflower downy mildew) from Hungary. Plant Pathology 44, 619-624 (1995).

31. Szécsi,Á., Möller,E.M.: Identification of Gibberella fujikuroi isolates by RAPD-PCR analysis. (in Hungarian) Növényvédelem 33, 229-234 (1997).

32. Fekete,Cs., Hornok,L.: A repetitive DNA sequence associated with karyotype variability in Fusarium poae. Acta Phytopathol Entomol Hung 32, 29-38 (1997).

33. Turóczi,Gy., Vajna,L., Bratek,Z.: More Trichoderma species from Hungary. Acta Phytopathol Entomol Hung 29, 259-271 (1994).

34. Kiss,L:: Genetic diversity in Ampelomyces isolates, hyperparasites of powdery mildew fungi, inferred from RFLP analysis of the rDNA ITS region. Mycol Res 101, 1073-1080 (1997).

35. Radócz,L., Szabó,I., Varga,M.: Biological control of chestnut blight [Cryphonectria parasitica (Murr.) Barr.] in Hungary. (in Hungarian) Növényvédelem 33, 3-10 (1997).

36. Schwarzinger,L., Vajna,L., Bruckart,W.L.: First report of Colletotrichum gloeosporioides on Russianthistle. Plant Disease 82, 1405 (1998) 